\title{
Effects of different floor housing systems on the welfare of fast-growing broilers with an extended fattening period
}

\author{
Enver Çavuşoğlu ${ }^{1}$, Metin Petek ${ }^{1}$, İbrahima Mahamane Abdourhamane ${ }^{1}$, Ahmet Akkoc ${ }^{2}$, and \\ Ersin Topal ${ }^{1}$ \\ ${ }^{1}$ Department of Animal Science, Faculty of Veterinary Medicine, University of Uludag, Bursa, Turkey \\ ${ }^{2}$ Department of Pathology, Faculty of Veterinary Medicine, University of Uludag, Bursa, Turkey \\ Correspondence: Metin Petek (petek@uludag.edu.tr)
}

Received: 9 August 2017 - Revised: 24 November 2017 - Accepted: 1 December 2017 - Published: 16 January 2018

\begin{abstract}
This study was made to investigate the long-term effects of different floor housing systems on the welfare of fast-growing broilers. The experiment was performed on 210-day-old fast-growing hybrid male chickens with identical conditions until 47 days of age. Animal-based welfare parameters were measured to investigate the welfare level in the group housed on deep litter, a litter and slat system, and a slatted floor, with five replicates for each group. Results showed that the main welfare indicators in live birds, such breast dirtiness, plumage score, footpad lesion, and hock burn lesion, were negatively affected in broilers kept on conventional deep-litter floor housing. But hemorrhage or lesion scores of the breast and shoulder of broilers in slat floor housing were found to be significantly greater than in conventional deep litter as a result of a heavy body weight at a greater slaughter age $(p<0.05)$. Pathologically, the prevalence of footpad and hock joint dermatitis was very high in the deep-litter housing system. Femoral head necrosis was not observed in any floor housing group. The results indicated that keeping broilers on a slat flooring system is preferable for younger slaughter ages and for a lighter slaughter weight. When considering the relationship between animal welfare and production economy, moving from one floor house system to another floor housing system should be carefully weighted in future decisions. Moreover, further investigations are needed in order to examine the incidence of joint and bone problems with muscle inflammation in heavier broilers in commercial conditions.
\end{abstract}

\section{Introduction}

Deep-litter floor housing is most common when raising broiler chickens used for white meat production (Appleby et al., 1992; North and Bell, 1990; Aviagen, 2016). In this system, better litter management is crucial for providing good litter quality and for controlling the ammonia level inside the poultry houses. If litter and inside air quality are not optimal, there will be a considerable risk of the birds developing respiratory diseases and contact dermatitis on their feet and breast (Cengiz et al., 2013; De Jong et al., 2014; Petek et al., 2015). However, keeping litter dry and in good condition in deep-litter floor housing is very difficult due to drinker type, bedding material, outdoor and indoor temperature and humidity, the ventilation system, and high stocking density (Musilova et al., 2013; Petek et al., 2014). Wet and unsuitable litter reduces overall welfare, technical performance, and car- cass yield in broiler chickens (De Jong et al., 2014; Petek et al., 2014). A variety of floor materials have been tested for many years in broiler production (Da Cruz et al., 2013; Jacob et al., 2016). Although cage and slat floor housing have been available for many years, they have not been widely adopted because of poor leg health and poor meat quality of broilers (Shields and Grager, 2013). Currently, in some parts of South Asia and Russia, cages or batteries with slatted or plasticcoated wire flooring without any supplementary bedding material are popular in broiler production as a result of recent technological improvements in the material of the cage surface (Prabakaran, 2003; Bilal et al., 2014). In general, the colony cage system is used in broiler production, with cages each being $181 \mathrm{~cm}$ wide and $240 \mathrm{~cm}$ long. However, due to the limited space and conditions inappropriate for the natural behavior of broilers, the cage system has been criticized in terms of animal welfare as has also happened with regard 
to egg production (Özhan et al., 2016). Therefore, slat floor housing is likely to be a more appropriate flooring system for broiler production (Bilgili et al., 2009; Petek et al., 2015).

There is a trend to produce broilers of greater body weight because of the increasing demand for processed products. Broiler hybrids that are used for such kinds of production have been intensively selected for a fast growth rate and breast meat yield and are reared for a longer period than standard broilers. Increasing age at slaughter also affects the cooking yield and the shear force value of the cooked meat (Northcutt et al., 2001). Additionally, broiler chicken welfare parameters, such as lameness (Knowles et al., 2008), hock and footpad lesions, and dermatitis, are also affected by slaughter age, live weight, and housing conditions (Shepherd and Fairchild, 2010; Dawkins et al., 2017). The effects of the age or live weight of broilers raised in different floor housing have not been investigated enough with regard to contact dermatitis, arthritis, and hock and footpad lesions in broiler production (Ekstrand et al., 1997; Jones et al., 2005; Meluzzi et al., 2008; Allain et al., 2009). This study planned to evaluate the effects of different floor housing systems on some welfare parameters of fast-growing broilers slaughtered at 47 days of age.

\section{Materials and methods}

This study was conducted at the Research and Experimental Farm of Uludag University in Bursa in Turkey. The experimental procedures were employed in accordance with the principles and guidelines set out by the Committee of Uludag University on animal care. In the experiment, a total of 210day-old fast-growing male broiler chicks $\left(\right.$ Ross $\left.\mathrm{PM}_{3}\right)$ were randomly assigned to three equal groups, with five replicates each. The groups were as follows: slatted floor, litter and slatted-floor system, and deep-litter flooring. The birds in the experiment were raised in identical conditions, and they were slaughtered at 47 days of age. Birds in all groups received a commercial multiphase diet (i.e., starter from days 0-15, grower I from days 15-30, grower II from days 30-40, and finisher from days 40-47), which was produced and supplied by a commercial feed company in Turkey.

\subsection{Data}

In the study, gait and walking ability, feather coverage, dirtiness of the breast, footpad lesion, and hock burn lesion of the live birds were assessed visually by the same person at the end of the experiment. Haemorrhage or lesion of the skin of the breast, pygostyle, shoulder, and wings were assessed after the slaughter process. Moreover, the development and severity of footpad dermatitis, hock joint dermatitis, hock joint arthritis, and femoral head necrosis of the selected and phenotypically affected birds were investigated pathologically. From each group, 10 broiler feet from 10 individuals (left leg only, $n=30$ in total) were randomly sampled and then subjected to macroscopic and microscopic examinations.

In live birds, walking ability was assessed first using the scoring system developed by Kestin et al. (1992). The methodology consists of visual observations of how birds walk on a surface. The system is divided into six levels as follows: 0 (healthy bird); 1 (the bird moves fast, but a slight walking deficiency is observed); 2 (the bird moves fast, but there is significant walking deficiency); 3 (the bird moves fast, but it presents an important deficiency); 4 (the bird moves with serious difficulty); and 5 (the bird barely moves and often uses the wings for crawling). Hock burn was assessed using four levels: no lesion on hocks (0); minimal (1) or superficial lesions (2); moderate or severe lesions (3) (Welfare Quality Consortium, 2009; Butterworth, 2013). Footpad lesions were scored according to five levels: a score of 0 indicated no lesion, 1 indicated a very small or superficial lesion, 2 indicated a mild lesion (minor superficial lesion), 3 indicated a medium-severity lesion (moderate hyperkeratosis), and 4 indicated a severe lesion (deep and large epithelial necrosis) (Pagazaurtundua and Warris, 2006; Welfare Quality Consortium, 2009; Butterworth, 2013). Feather coverage of each bird was scored on a scale of 0 to 2 (Dawkins et al., 2004; Welfare Quality Consortium, 2009). A plumage score of 0 indicated hens with full feather cover (best); a score of 0.5 indicated hens with slight patchiness on the sides or back of the body or on the wings; a score of 1 indicated that feather cover is patchy to bare on the sides or the back of the body; 1.5 meant that there is no feather cover on the sides of the body and only a light covering on the back; 2.0 indicated that the body is bare of feathers and the wings have a patchy cover of feathers (worst score). Breast plumage dirtiness was scored visually from 1 (very clean) to 8 (very dirty) as reported by Wilkins et al. (2003). Haemorrhage or lesions on the pygostyle, wing, breast, and shoulder were scored according to animal welfare grading standards (Bristol University, 2010). They were recorded as follows: pygostyle $-0,1$, and 2 (worst); wing tip $-0,1,2$, and 3 (worst); breast - 0 (best), 1, 2, and 3; shoulder haemorrhage -0 (best), 1, 2, and 3. The litter of each deep-litter pen and litter and slat pen received a score between 0 (very wet) to 10 (completely dry) from two independent observers (De Jong and Gunnik, 2014).

After slaughtering, sampled legs were evaluated by macroscopic and microscopic examinations, and gross images were obtained from the legs. For the footpad dermatitis and hock joint dermatitis, a macroscopic examination scoring system was created by modifying Kaukonen et al. (2016). Inflammatory changes, such as swelling of the joint capsule and the existence of exudate within intra-articular spaces in leg joints, were evaluated and scored. Histopathological examinations were done routinely. For this purpose, tissue samples (footpad tissue, tarsal articular joint samples including skin and synovial membrane) were placed in a $10 \%$ buffered formaldehyde solution and fixed for $48 \mathrm{~h}$. Subsequently, the 
Table 1. The mean values and standard error of the mean (SEM) of the live body weight of broilers in the different groups $(g)$. Df is degrees of freedom.

\begin{tabular}{lrrrr}
\hline Housing group & & & & \\
\hline Parameter/groups & Deep litter & Slatted floor & Litter and slat & \\
\hline Body weights, $g$ & $3260 \pm 71^{\mathrm{b}}$ & $3524 \pm 66^{\mathrm{a}}$ & $3478 \pm 84^{\mathrm{a}}$ & \\
\hline ANOVA & & & & \\
\hline Df between groups & Df within groups & Df total & $F$ values & $p$ values \\
2 & 93 & 95 & 5.277 & 0.007 \\
\hline${ }^{\mathrm{a}-\mathrm{b}}$ Different superscripts indicate statistical significant difference among the groups. &
\end{tabular}

tissues were dehydrated with graded alcohols and cleaned in xylene solutions and then embedded in paraffin. Tissue samples were cut to $4 \mu \mathrm{m}$ and stained with hematoxylin and eosin and examined under a light microscope. Gross and histopathologic evaluations were largely based on Michel et al. (2012). However, a slight modification was made since there were no cases of slight redness or abrasion in the specimens. During scoring, score I was to indicate the absence of prominent lesions, score II was used for lesions with scabs and small necrotic-ulcerative areas smaller than $1 \mathrm{~cm}^{2}$, and score III was used for lesions with scabs and necroticulcerative areas larger than $1 \mathrm{~cm}^{2}$. Hyperkeratosis, acanthosis, erosions, ulcers, cell debris, crusting, and inflammatory cells were assessed in histopathological examinations on the basis of whether they were damaged (erosions with intact basement membrane, hyperkeratosis and acanthosis, deep ulcerative lesions, cellular debris, and heavy infiltrations) or undamaged (no lesions).

\subsection{Statistical analysis}

All data were statistically analyzed using the SPSS computer software 13.00 (SPSS 2004). According to the distribution of the data, the scores of the gait, breast dirtiness, feather cover, footpad, hock joint, and hemorrhage or lesion scores of the breast, pygostyle, wings, and shoulder of broiler carcasses were subjected to nonparametric statistical analysis, using the Kruskal-Wallis test. The Mann-Whitney $U$ test was used to compare different groups after the test including Bonferroni correction. Live body weight was evaluated by an analysis of variance (ANOVA). Mean separation for the body weight was performed using the Duncan test (Snedecor and Cochran, 1989). No statistical test was done for the prevalence of footpad and hock joint dermatitis, hock joint arthritis, and femoral head necrosis.

\section{Results and discussion}

A litter-bedded floor system is most common for commercial broiler meat production. Throughout the world, the majority of broiler meat is produced using wood shaving or rice hull as bedding material. Continued interest in rearing broilers on different flooring systems apart from litter may be attributed to one of a number of major factors: chickens' contact with fecal material and its hazardous effect (Reece et al., 1971; Petek et al., 2015). Our study systemically compared deep litter with fully or semi-slatted flooring (litter + slat) systems for broilers by comparing animal welfare parameters during 47 days. The live body weight of the broiler in the groups is presented in Table 1.

The average body weight of broilers was significantly higher in the slatted-floor housing group and the litter + slat group in comparison to the conventional deep-litter floor housing group. The litter was very wet, with a score of 0 or 1 in the deep-litter groups. A strong ammonia odor and close contact with manure in this group may be due to the effect of the live body weight of broilers (Sahoo et al., 2017). In a study, it was reported that broiler production performance, including live weight, feed conversion, and mortality, was not affected by the netting floor compared to the litter system, and the welfare quality parameters, including hock and footpad lesions, lameness, and anxiety levels, were similar in both flooring systems ( $\mathrm{Li}$ et al., 2017). In that study, the results suggest that birds raised in the netting floor house may be exposed to a higher incidence of breast blistering. Summary statistics of gait, breast dirtiness, feather cover, and footpad and hock joint lesion scores in the experiment are presented in Table 2.

In broiler production, the foot, hock, and breast burn lesions are indicators of housing conditions and the general welfare of the birds. Wet litter is the most important factor causing dermatitis in the footpad, hock burn, and breast of broiler chicks (Haslam et al., 2007). In this study, locomotion (gait score) was not negatively affected by the floor housing system. According to the results the birds in all groups move fast, but a slight walking deficiency was observed in some birds. As expected (Wilkins et al., 2003), the breast feathers of the birds in the deep-litter system were quite dirty and had a significantly greater score than in the other system as a result of close contact with poor-quality manure. Feathering scores for the breast of broilers were affected by the floor housing and were the best in a litter + slat system. The deep- 
Table 2. Summary statistics of gait, breast dirtiness, feather cover, and footpad and hock joint lesion scores in the experiment. Df is degrees of freedom.

\begin{tabular}{|c|c|c|c|c|c|c|}
\hline \multirow[b]{2}{*}{ Parameters } & \multicolumn{3}{|c|}{ Housing group } & \multirow[b]{2}{*}{$p$ value } & \multirow[b]{2}{*}{ Chi-square value } & \multirow[b]{2}{*}{ Df } \\
\hline & $\begin{array}{l}\text { Slatted-floor median } \\
\text { (min.-max.) } \\
\text { Q3-Q1 }\end{array}$ & $\begin{array}{l}\text { Deep litter } \\
\text { median (min.-max.) } \\
\text { Q3-Q1 }\end{array}$ & $\begin{array}{l}\text { Litter + slat } \\
\text { median (min.-max.) } \\
\text { Q3-Q1 }\end{array}$ & & & \\
\hline Gait & $\begin{array}{l}0.00(0.00-5.00) \\
(0.00-0.00)\end{array}$ & $\begin{array}{l}0.00(0.00-1.00) \\
(0.00-0.00)\end{array}$ & $\begin{array}{l}0.00(0.00-5.00) \\
(1.00-0.00)\end{array}$ & 0.070 & 5.315 & 2 \\
\hline Breast dirtiness & $\begin{array}{l}2.00(0.00-5.00) \\
(3.00-1.00)^{\mathrm{c}}\end{array}$ & $\begin{array}{l}7.00(7.00-8.00) \\
(8.00-7.00)^{\mathrm{a}}\end{array}$ & $\begin{array}{l}4.00(2.00-8.00) \\
(5.00-3.00)^{\mathrm{b}}\end{array}$ & 0.000 & 70.688 & 2 \\
\hline Feather cover & $\begin{array}{l}0.50(0.00-1.50) \\
(1.00-0.50)^{\mathrm{b}}\end{array}$ & $\begin{array}{l}1.50(1.00-2.00) \\
(2.00-1.50)^{\mathrm{a}}\end{array}$ & $\begin{array}{l}1.00(0.00-2.00) \\
(1.00-0.50)^{\mathrm{b}}\end{array}$ & 0.000 & 51.259 & 2 \\
\hline Footpad lesion & $\begin{array}{l}0.00(0.00-1.00) \\
(0.00-0.00)^{\mathrm{c}}\end{array}$ & $\begin{array}{l}3.00(0.00-4.00) \\
(4.00-2.00)^{\mathrm{c}}\end{array}$ & $\begin{array}{l}0.00(0.00-4.00) \\
(1.00-0.00)^{\mathrm{b}}\end{array}$ & 0.000 & 59.669 & 2 \\
\hline Hock burn lesion & $\begin{array}{l}0.00(0.00-2.00) \\
(0.75-0.00)^{\mathrm{b}}\end{array}$ & $\begin{array}{l}2.00(0.00-2.00) \\
(2.00-1.00)^{\mathrm{a}}\end{array}$ & $\begin{array}{l}0.00(0.00-2.00) \\
(1.00-0.00)^{\mathrm{b}}\end{array}$ & 0.000 & 39.721 & 2 \\
\hline
\end{tabular}

${ }^{a-c}$ Different superscripts indicate statistical significant difference among the groups.

Table 3. Median, minimum and maximum scores* and of the hemorrhage or lesion scores of the breast, pygostyle, wings, and shoulder of broiler carcasses in the experiment.

\begin{tabular}{|c|c|c|c|c|c|c|}
\hline \multirow[b]{2}{*}{ Parameters } & \multicolumn{3}{|c|}{ Housing group } & \multirow[b]{2}{*}{$p$ value } & \multirow[b]{2}{*}{ Chi-square value } & \multirow[b]{2}{*}{$\mathrm{df}$} \\
\hline & $\begin{array}{l}\text { Slatted-floor } \\
\text { median (min.-max.) } \\
\text { Q3-Q1 }\end{array}$ & $\begin{array}{l}\text { Deep litter } \\
\text { median (min.-max.) } \\
\text { Q3-Q1 }\end{array}$ & $\begin{array}{l}\text { Litter }+ \text { Slat } \\
\text { median (min.-max.) } \\
\text { Q3-Q1 }\end{array}$ & & & \\
\hline Breast & $\begin{array}{l}1.00(0.00-3.00) \\
(1.25-0.00)\end{array}$ & $\begin{array}{l}0.00(0.00-3.00) \\
(1.00-0.00)\end{array}$ & $\begin{array}{l}0.00(0.00-2.00) \\
(1.00-0.00)\end{array}$ & 0.313 & 2.326 & 2 \\
\hline Pygostyle & $\begin{array}{l}0.00(0.00-2.00) \\
(1.00-0.00)\end{array}$ & $\begin{array}{l}0.00(0.00-1.00) \\
(1.00-0.00)\end{array}$ & $\begin{array}{l}0.00(0.00-2.00) \\
(0.00-0.00)\end{array}$ & 0.082 & 5.006 & 2 \\
\hline Wings & $\begin{array}{l}0.00(0.00-3.00) \\
(1.00-0.00)\end{array}$ & $\begin{array}{l}0.00(0.00-3.00) \\
(1.00-0.00)\end{array}$ & $\begin{array}{l}0.00(0.00-3.00) \\
(1.00-0.00)\end{array}$ & 0.545 & 1.212 & 2 \\
\hline Shoulder & $\begin{array}{l}0.00(0.00-2.00) \\
(1.00-0.00)\end{array}$ & $\begin{array}{l}0.00(0.00-2.00) \\
(0.00-0.00)\end{array}$ & $\begin{array}{l}0.00(0.00-2.00) \\
(1.00-0.00)\end{array}$ & 0.117 & 4.284 & 2 \\
\hline
\end{tabular}

* Lower scores indicate better welfare.

litter floor housing group had significantly more hock burns and footpad irritations. The main factor contributing to the development of lesions on the footpad or hock was the poor litter quality. Substrates with sharp edges may increase the prevalence and the severity of dermatitis (Jacob et al., 2016). Footpad dermatitis causes pain and therefore has a negative effect on bird welfare.

The median values of haemorrhages on the breast, pygostyle, wings, and shoulder of broiler carcasses in all groups were not significantly different (Table 3). Hemorrhages in muscle tissue can be considered major quality defects of broiler carcasses. A higher slaughter age and heavier live weight can be the most important factor for hemorrhages in muscle tissue in broilers. At certain times, there may be a higher demand for heavy broilers. A higher body weight and slaughter age are sometimes associated with an increased density of contact dermatitis and consequent carcass down- grading of deboned parts and products as well as for readyto-cook products.

Pathologically, footpad and hock joint dermatitis were very common in the litter-based system. The prevalence of hock joint arthritis was calculated as being $40.00 \%$ in the slatted-flooring system and $20.00 \%$ in the litter + slat floor housing group (Table 4). The presence of femoral head necrosis was not observed in any floor housing group. Rough handling during catching and the slaughter process is a major cause of bruised wings or legs in broilers (Grandin, 2010), and this may also increase the severity of haemorrhages.

Macroscopic and microscopic features of footpads and hock joint in healthy and affected animals are presented Figs. 1 and 2.

The histological analysis of footpad dermatitis lesions allowed the accurate determination of the different kinds of lesions and hence their impact on animal welfare. Michel 

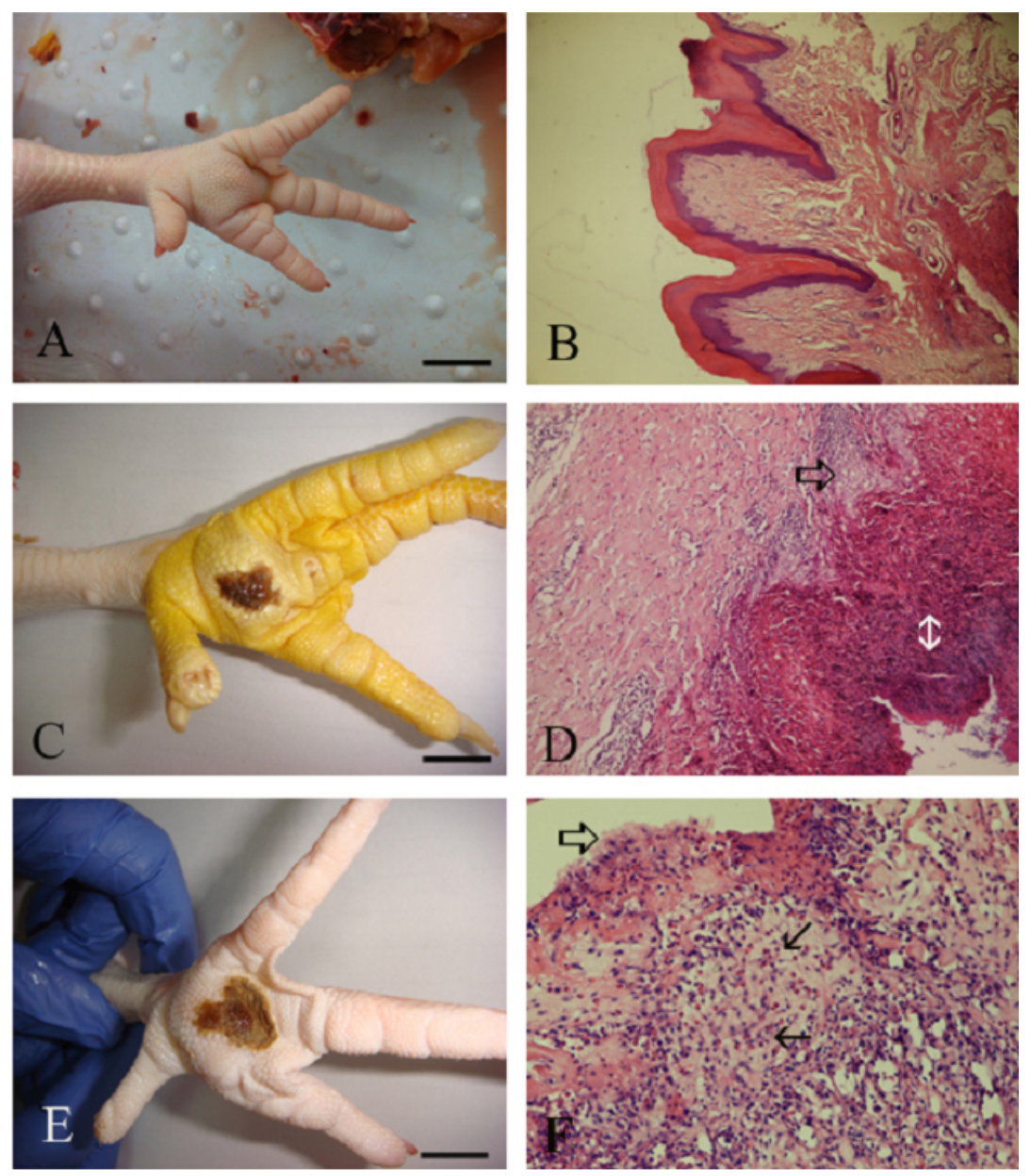

Figure 1. Macroscopic and microscopic features of footpads in healthy and affected animals. Score I: (a) no prominent lesion is visible on the footpad, with normal skin and no discolouration (S1); the microscopical appearance of the skin structure is normal (b). Bar: $1 \mathrm{~cm}$; 100x magnification. Score II: (c) gross view of ulcerative lesion $\left(<1 \mathrm{~cm}^{2}\right)$ and scab formation in the skin of footpad dermatitis. Bar: $1 \mathrm{~cm}$. (d) Histopathological features of affected skin; erosive and ulcerative epidermis (open arrow); degenerative and necrotic epidermal cells in scab (double headed arrow). 200x magnification. Score III: (e) gross view of ulcerative lesion (score SIII) $\left(>1 \mathrm{~cm}^{2}\right)$ and scab formation with brown discoloration in the skin of footpad dermatitis. Bar: $1 \mathrm{~cm}$. (f) Histopathological features of the footpad; ulcerative surface of skin (open arrow); heavy infiltration of the dermis by heterophiles and other monocytic cells (arrows). 200x magnification.

Table 4. The prevalence of footpad dermatitis, hock joint dermatitis, hock joint arthritis, and femoral head necrosis (\%).

\begin{tabular}{lrrr}
\hline Parameter & $\begin{array}{r}\text { Deep } \\
\text { litter }\end{array}$ & $\begin{array}{r}\text { Slatted } \\
\text { Floor }\end{array}$ & $\begin{array}{r}\text { Litter } \\
\text { and slat }\end{array}$ \\
\hline Footpad dermatitis & 60.00 & 0.00 & 60.00 \\
Hock joint dermatitis & 60.00 & 20.00 & 80.00 \\
Hock joint arthritis & 0.00 & 40.00 & 20.00 \\
Femoral head necrosis & 0.00 & 0.00 & 0.00 \\
\hline
\end{tabular}

et al. (2012) were the first to propose a scoring system for broiler footpad dermatitis validated by histological analysis. This five-point scoring system is already in use in several French slaughterhouses. A healthy footpad and hock joint were defined as having no visible lesion, no discolouration, and histologically normal scales without significant inflammatory changes. The microscopic lesions diagnosed in this study were almost similar to those described in previous studies (Martland, 1984, 1985; Greene et al., 1985). Score II lesions corresponded to a more severe stage of inflammation, and score II lesions were apparent at the periphery of the ulcer. Score III lesions often consisted of severe ulceration, covered by necrotic and suppurative material and with underlying granulation tissue (Fig. 1). Ulcerative lesions, cutaneous lesions, and inflammation have been considered to be painful (Young, 2007; Flecknell, 2008). 

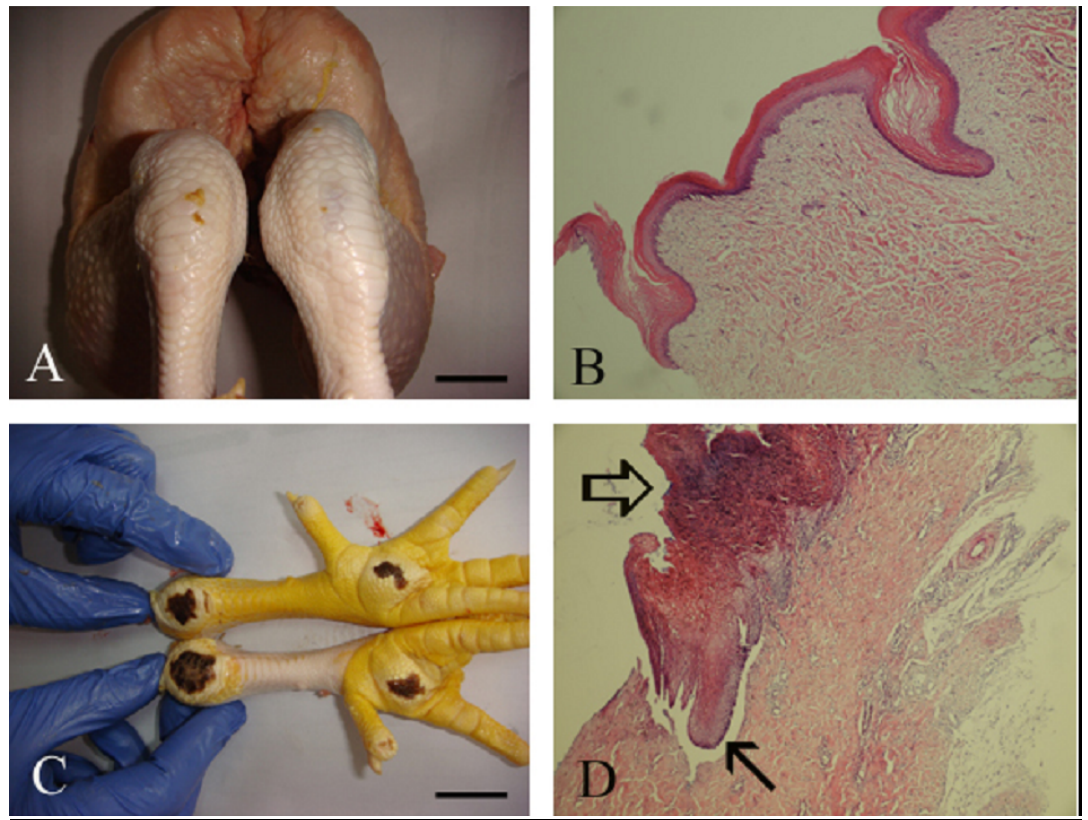

Figure 2. Gross and histopathological evaluation of hock joints in healthy and affected birds. Undamaged ((a) and (b)): macroscopical and microscopical view of hock joint skin in a healthy bird and its microscopical reflection. (SI score with no lesion.) Bar: 1 cm; 100x magnification. Damaged ((c)): upper leg, SII lesion with ulceration and scab formation $\left(<1 \mathrm{~cm}^{2}\right)$ with brown discoloration; lower leg displays SIII lesion with ulceration and scab formation $\left(>1 \mathrm{~cm}^{2}\right)$ with brown discoloration in affected birds. Bar: $2 \mathrm{~cm}$. (d) Microscopical view of SII and SIII lesions with larger ulceration (arrow) and scab formation (open arrow) in an affected bird. 200x magnification.

\section{Conclusions}

In terms of sustainability, keeping broilers on a slat flooring system should be preferred, especially with a low slaughter age and light slaughter weight, not only because footpad lesions have an impact on the economic value of the bird but also because of the negative correlation with broiler weight and downgraded carcass quality. As in the other systems, proper ventilation and other management practices are very important in slat floor housing, especially for a higher slaughter age. It should be considered that there is less or no litter cost in slat floor housing, except for the initial investment. Further investigations are needed to investigate the incidence of joint and bone problems with muscle inflammation (meat quality) in heavier broilers with a greater slaughter age in commercial conditions.

Data availability. Data are available from the corresponding author upon request.

Author contributions. MP conceived and designed the experiment; EC, AA, ET, and IMA performed the experiments; MP, ET, and EC analyzed the data; MP wrote the paper.
Competing interests. The authors declare that they have no conflict of interest.

Acknowledgements. No funding was received on the subject of this paper.

Edited by: Manfred Mielenz

Reviewed by: two anonymous referees

\section{References}

Allain, V., Mirabito, L., Arnould, C., Colas, M., Le Bouquin, S., Lupo, C., and Michel, V.: Skin lesions in broiler chickens measured at the slaughterhouse: relationships between lesions and between the prevalence and rearing factors, Brit. Poultry Sci., 50, 407-417, 2009.

Appleby, M. C., Hughes, B. O., and Elson., H. A.: Poultry production systems: behaviour, management and welfare, CAB International, Wallingford, UK, 1992.

Aviagen: A guide to managing broilers in open-sided housing, available at: http://en.aviagen.com/assets/ Tech_Center/Broiler_Breeder_Tech_Articles/English/ AVIAEnvMgtOpenSidedHseBroiler-EN-2016.pdf (last access: 17 November 2017), 2016.

Bilal, K., Mehmood, S., Akram, M., Imran, S., Sahota, A. W., Javed, K., Hussain, J., and Ashfaq, A.: Growth performance of broilers under two rearing systems in three different housing 
zones in an envrionmentally controlled huse during winter, J. Anim. Plant Sci., 24, 1039-1044, 2014.

Bilgili, S. F., Hess, J. B., Blake, K. S., Macklin, N., Saenmmahayak, B., and Sibley, J. L.: Influence of bedding material on footpad dermatitis in broiler chickens, J. Appl. Poultry. Res., 18, 583-589, 2009.

Bristol University: Animal Welfare Officier Training Leaflets: Broiler shoulder, wing, pygostyle haemorrhages grading standards, UK, 2010.

Butterworth, A.: On-farm broiler welfare assessment and associated training, Rev. Bras. Cienc. Avic., 15, 71-78, 2013.

Cengiz, O., Hess, J. B., and Bilgili, S. F.: Effect of protein source on the development of footpad dermatitis in broiler chickens reared on different flooring types, Arch. Tierzucht., 77, 166-170, 2013.

Da Cruz, D. P., Otutumi, L. K., Junior, R. P., Cervantes, R. P., Mezalira, T. S., and Geronimo, E.: Performance, Carcass yield and litter quality of broilers raised on litters treated with microorganisms, Ci. Anim. Bras. Goiânia, 14, 41-48, 2013.

Dawkins, M. S., Donnelly, C. A., and Jones, T. A.: Chicken welfare is influenced more by housing conditions than by stocking density, Nature, 427, 342-344, 2004.

Dawkins, M. S., Roberts, S. J., Cain, R. J., Nickson, T., and Donnelly, C. A.: Early warning of footpad dermatitis and hockburn in broiler chicken flocks using optical flow, bodyweight and water consumption, Vet. Rec., 11, 1-5, 2017.

De Jong, I. C. and Gunnink, H.: Wet litter not only induces footpad dermatitis but also reduces overall welfare, technical performance, and carcass yield in broiler chickens, J. Appl. Poultry. Res., 23, 51-58, 2014.

De Jong, I. C., Gunnink, H., and Hindle, V.: Implementation of the Welfare Quality broiler monitor on Dutch broiler farms, Proc. 6th Int. Conf. Assessment of Anim. Welf. at Farm and Group Level, 3-5 September 2014, Clermont-Ferrand, France, 70, 2014.

Ekstrand, C., Algers, B., and Svedberg, J.: Rearing conditions and foot-pad dermatitis in Swedish broiler chickens, Prev. Vet. Med., 31, 167-174, 1997.

Flecknell, P.: Analgesia from a veterinary perspective, Brit. J. Anaesth., 101, 121-124, 2008.

Grandin, T.: Welfare during transport of livestock and poultry, in: Improving Animal Welfare: A Practical Approach, edited by: Tempel Grandin, Second Edition, CABI Publishing: Wallingford, UK, 2010.

Greene, J. A., Mc Cracken, R. M., and Evans, R. T.: A contact dermatitis of broilers-clinical and pathological findings, Avian. Pathol., 14, 23-38, 1985.

Haslam, S. M., Knowles, T. G., Brown, S. N., Wilkins, L. J., Kestin, S. C., Warriss, P. D., and Nicol, C. J.: Factors affecting the prevalence of foot pad dermatitis, hock burn and breast burn in broiler chicken, Brit. Poultry Sci., 48, 264-275, 2007.

Jacob, F. G., Baracho, Nääs, I. A., Lima, N. S. D., Salgado, D. D., and Souza, R.: Risk of incidence of hock burn and pododermatitis in broilers reared under commercial conditions, Rev. Bras. Cienc. Avic., 18, 357-362, 2016.

Jones, T.A, Donnelly, C. A., and Dawkins, M. S.: Environmental and management factors affecting the welfare of chickens on commercial farms in the United Kingdom and Denmark stocked at five densities, Poultry. Sci., 84, 1155-1165, 2005.
Kestin, S. C., Knowles, T. G., Tinch, A. E., and Gregory, N. G.: Prevalence of leg weakness in broiler chickens and its relationship with genotype, Vet. Rec., 131, 190-194, 1992.

Knowles, T. G., Kestin, S. C., Haslam, S. M., Brown, S. N., Green, L. E., Butterworth, A., Pope, S. J., Pfeiffer, D., and Nicol, C. J.: Leg disorders in broiler chickens: prevalence, risk factors and prevention, Plos One, 3, e1545, https://doi.org/10.1371/journal.pone.0001545, 2008.

Kukonen, E., Norring, M., and Valros, A.: Effect of litter quality on foot pad dermatitis, hock burns and breast blisters in broiler breeders during the production period, Avian. Pathol., 45, 667673, 2016.

Li, H., Wen, X., Alphin, R., Zhu, Z., and Zhou, Z.: Effects of two different broiler flooring systems on production performances, welfare, and environment under commercial production conditions, Poultry. Sci., 96, 1108-1119, 2017.

Martland, M. F.: Wet litter as a cause of plantar pododermatitis, leading to foot ulceration and lameness in fattening turkeys, Avian. Pathol., 13, 241-252, 1984.

Martland, M. F.: Ulcerative dermatitis in broiler chickens: the effects of wet litter, Avian. Pathol., 14, 353-364, 1985.

Meluzzi, A., Fabbri, C., Folegatti, E., and Sirri, F.: Survey of chicken rearing conditions in Italy: effects of litter quality and stocking density on productivity, foot dermatitis and carcase injuries, Brit. Poultry Sci., 49, 257-264, 2008.

Michel, V., Prampart, E., Mirabito, L., Allain, V., Arnould, C., Huonnic, D., Le Bouquin, S., and Albaric, O.: Histologicallyvalidated footpad dermatitis scoring system for use in chicken processing plants, Brit. Poultry Sci., 53, 275-281, 2012.

Musilová, A., Lichovníková, M., Hampel, D., and Przywarová, A.: The effect of the season on incidence of footpad dermatitis and its effect on broilers performance, Acta Univ. Agric. Silvic. Mendelianae Brun., 61, 1793-1798, 2013.

North, B. B. and Bell, D. D.: Commercial Chicken Production Manual, Chapman \& Hall, New York, USA, 1990.

Northcutt, J. K., Buhr, R. J., Young, L. L., Lyon, C. E., and Ware, G. O.: Influence of age and postchill carcass aging duration on chicken breast fillet quality, Poultry. Sci., 80, 808-812, 2001.

Özhan, N., Simsek, U. C., and Ozcelik, M.: Comparison of floor and cage housing systems in terms of some welfare assessments in broiler, Kafkas Univ. Vet. Fak., 63, 317-322, 2016.

Pagazaurtundua, A. and Warris, P. D.: Levels of foot pad dermatitis in broiler chickens reared in 5 different systems, Brit. Poultry Sci., 47, 529-532, 2006.

Petek, M., Ustüner, H., and Yesilbag, D.: Effects of stocking density and litter type on litter quality and growth performance of broiler chicken, Kafkas Univ. Vet. Fak., 20, 743-748, 2014.

Petek, M., Çavuşoğlu, E., Topal, E., Ünal, C., and Abdourhamane, I. M.: Effects of slatted floor housing on animal welfare in broiler production, 3rd Internatinal Poultry Meat Congress, 22-26 April 2015, Antalya, Turkey, Proceedings, 2015.

Prabakaran, R.: Good practices in planning and management of integrated commercial poultry production in South Asia, chap. 3, FAO, Rome, Italy, 9-24, 2003.

Reece, F. N., Deaton, J. W., May, J. D., and May, K. N.: Cage versus floor rearing of broiler chickens, Poultry. Sci., 50, 1786-1790, 1971. 
Sahooa, S. P., Kaura, D., Sethib, A. P. S., Sharmaa, A., and Chandrac, M.: Effect of chemically amended litter on litter quality and broiler performance in winter, J. Appl. Anim. Res., 45, 533-537, 2017.

Shepherd, E. M. and Fairchild, B. D.: Footpad dermatitis in poultry, Poultry. Sci., 89, 2043-2051, 2010.

Shields, S. and Greger, M.: Animal welfare and food safety aspects of confining broiler chickens to cages, Animals, 3, 386400, 2013.

Snedecor, G. W. and Cochran, W. G.: Statistical Methods, Eigth Edition, Iowa State University Press, Ames, IA, USA, 1989.
SPSS $^{\circledR}$ 13.00: Computer Software: SPSS Inc, Chicago, IL, USA, 2004.

Welfare Quality Consortium: Welfare quality assessment protocol for poultry (broilers, laying hens), available at: http:// www.welfarequalitynetwork.net/network/45848/7/0/40 (last access: 17 November 2017), 2009.

Wilkins, L. J., Brown, S. N., Phillips, A. J., and Warris, P. D.: Cleanliness of broilers when they arrive at poultry processing plants, Vet. Rec., 153, 701-703, 2003.

Young, T.: Assessment of wound pain: overview and a new initiative, Br. J. Nurs., 16, 456-461, 2007. 